ISSN:

Print - $2277-078 \mathrm{X}$

Online - $2315-747 \mathrm{X}$

(c) FUNAAB 2016

Joumal of

Humanities, Social

Sciences and Creative Ants

\title{
SOCIETAL AWARENESS OF THE CHILD'S RIGHTS ACT AMONG RURAL AND URBAN DWELLERS OF OGUN STATE
}

\author{
IW. G. OJE BIYI, 10. R., ASHIMOLOWO, 1T. O. A. BAN MEKE AND \\ 2 A. M. ARIYO \\ Department of Agricultural Extension and Rural Development, \\ Department of Home Science and Management \\ Federal University of Agriculture, Abeokuta
}

Comesponding Author: oluwagbemiga2013@gmail.com Tel.: +2348067768470

\begin{abstract}
ABST RACT
Protecting the rights of children has become important to local and international agencies of government and non-governmental organizations. This led to the formulation of laws that provided for and protected the rights of the child. Such laws include the United Nation's Convention on the Rights of the Child, the African Charter on the Rights and Welfare of the Child, the Nigeria's Child's Rights Act (CRA) and the Child's Rights Law of Ogun State. However, the provisions of these documents seem to be inefficient in curbing the violation of child's rights due to the high prevalence of street hawking, raping, corporal punishment, etc among children in Nigeria and Ogun State in particular. Hence, this study sought the societal awareness of CRA in rural and urban areas of Ogun State. About 243 rural and urban residents were interviewed through multistage sampling techniques with the aid of questionnaires and interview schedules administered on the different groups of respondents. The result showed that $69.14 \%$ of Ogun State residents were aware of the CRA. It further revealed that awareness of CRA was higher in urban than rural areas. Awareness of CRA was primarily sourced through the radio (42.86\%) and television (42.86\%). Radio and awareness campaigns were the most common sources of awareness among rural (51.76\%) and urban (65.06\%) residents respectively. The study recommended that government agencies and non-governmental organizations should sponsor more programmes that will be specifically directed to raising residents' awareness of CRA in rural areas of the state.
\end{abstract}

Keywords: Children, CRA 2003, CRC, Residents, Societal awareness, Stakeholders

\section{INTRODUCTION}

Children are the precious gifts from God in order to ensure the continuity of man's existence. They are highly regarded by mankind to the existent that made many scholars to regard them as the future leaders and hence the hope of any Nation's social, political and economic development. D espite this, the society does not believe that children should have special rights because they assume that naturally adults serve the best interest of the child. However, with the prevalence of abuses and maltreatment of children, several human rights activists fought for the protection of children through several (international and local) chil- 
dren's rights documents.

The rights of the child was first legally recognized and protected through the Convention on the Rights of the Child (UNCRC) which came into existence on 20th November, 1989 after it was adopted by the United Nations General Assembly (UNICEF, 2007; Ejieh \& Akinola, 2009). The CRC was ratified by 191 out of 193 member States (with the exception of United States of America and Somalia) (Tang, 2003; UNICEF, 2006).

Before the existence of the CRC, rights of children were left to be traditionally protected by parents, guardians and other older persons in the society with the assumption that the adult would by nature serve the best interest of the child and thereby cater for his/ her needs (O wasanoye \& Adekunle, 1996). Thus, according to Augie (1998) cited in the work of Akwara, Adekunle \& Agba (2010), there was no need to think in terms of children's rights. This assumption became inadequate with the emergence of series of child abuse incidences such as sexual abuse, child exploitation through child labour and child trafficking to mention but a few. The nullification of this assumption led to the emergence of several movements and declarations which finally culminated into the Convention on the Rights of the Child that came into force in 1990.

To strengthen child's rights protection at the Continental level, the African Union (then Organization of African Unity) domesticated the content of the CRC into what is now proclaimed as the African Charter on the Rights and Welfare of the Child (ACRWC) in 1990 (UNICEF, 2007; Awosola \& Omoera, 2008). The essence of the domestication was to integrate peculiar
African culture into the document thus protecting African children against all forms of violence. As a result, the ACRWC was intended to suit the African society (Awosola \& O moera, 2008).

Nigeria ratified the UNCRC and the ACRWC in 1991 and 2000 respectively implying that the country committed itself to codes of binding obligations toward her children (Ejieh \& Akinola, 2009; Adimula, 2005). Among these obligations is the raising of awareness in the realization of children's rights. The two international instruments on the protection of child's rights were further domesticated via the enactment of the Child's Rights Act by the National Assembly in 2003 (The African Child Policy Forum, 2012). It must be noted that the Child's Rights Act did not become automatically applicable in the domestic jurisdiction by virtue of its ratification by the National Assembly because Nigeria is a dualist state (Brownlie, 1990 cited by the African Child Policy Forum, 2012) that operates a federal system of government which means that all states of the federation are semiautonomous. The implication is that the Act only becomes automatically and immediately operational at the federal level but not in any of the 36 states of the federation (Federal Government of Nigeria- FGN, 1999) and hence, the need for the domestication of the Act by the different states of the federation. However, the CRA therefore received a varied degree of acceptability across the states of the federation and almost all the southern states in Nigeria with the exception of Enugu and less than half of the northern states domesticated the Act. As at now, the Child's Rights Act, 2003 has been promulgated into law by the state assembly and assented to by the state governors in 24 states: Abia, Akwa-Ibom, Anambra, Bayelsa, Benue, 
Cross-River, Delta, Ebonyi, Edo, Ekiti, Imo, Jigawa, Kogi, Kwara, Lagos, Nassarawa, Niger, Ogun, Ondo, O sun, Oyo, Plateau, Rivers and Taraba states while the remaining 12 states are yet to have a law conforming to the CRA (UNICEF, 2011).

D espite the fact that $O$ gun State was one of the first states to domesticate the Act into the Child's Rights Law, many studies (including Ojebiyi, 2010; Agbonlahor, $\notin$ al. 2007; Ojo, 2013) have reported the prevalence of violations of child's rights in rural and urban areas of the state. Reasons adduced by scholars to the prevalence of these child abuse practices include that people are not aware of the existence of the Act (Okoye, 2011). According to Bamgboye (2011), even the Director General (then) of the Legal Aid Council in Nigeria, Mrs Joy Bob-Mannuel was of the view that the CRA has not received sufficient awareness and acceptance since its domestication. The knowledge of CRC and children's rights generally was reported to be lacking at all levels in most societies (the Society for Children and Youth of British Columbia, Canada, 2011 cited in Okoye, 2011).

It is believed that the menace of child abuse practices cannot be resolved when the people who are supposed to protect the rights of the children are not aware of the fact that children has some rights and that violations of these rights are punishable under the law. If the menace of child's rights violation continues, then the future is blurred for the state since children are the building blocks of any meaningful development in any area. Furthermore, the violation of children's rights through child labour, child marriage, abuse, neglect and trafficking will negatively affect child development since most children will be deprived quality education that is meant to prepare them morally, mentally and physically. Child labour, may also prevent the children from getting better jobs or becoming self-employed which could worsen their chances of escaping from the cycle of poverty.

In order to ensure sustainable development of the nation's economy, the development of children is of utmost importance. This is why G badamosi (2003) attributed child development to be fundamental for productive adulthood and according to Omotor (2002), children who grow in an enabling environment, well cultured, self-reliance, dignity, integrity and honesty are inculcated into them would become responsible adults equipped to overcome challenges and contribute positively to the Nation's economy. A veritable tool that can provide such an enabling environment towards proper development and survival of the child is the Child's Rights Act which serves the best interest of the child. It is in this direction that this study assessed the societal awareness of the CRA in rural and urban areas of O gun State, Nigeria with a view to comparing the level of awareness of the Act in rural and urban areas of the state. The objectives of the study were to determine the extent to which Ogun State residents were aware of CRA; identify the sources of awareness of CRA available to residents of $\mathrm{O}$ gun State; ascertain the agencies which sponsored CRA awareness programmes; determine the frequency with which Ogun State residents heard of CRA; and to ascertain the extent to which residents of O gun State were in contact with the CRA. The study hypothesis, stated in the null form, is that there is no significant association between the respondents' area of residence and their awareness of CRA. 


\section{METHODOLOGY}

The study was conducted in Ogun State. Ogun State located in South-western Nigeria was created from the old Western State on February 3, 1976 by the then regime of General Murtala Mohammed. It shares boundaries with Lagos State to the South, Oyo and Osun states to the North, Ondo State to the east and the Republic of Benin to the west. It lies between longitudes $2045^{\prime}$ and 30 55'; and latitudes 7001' and 70 and characterized by $1,000 \mathrm{~mm}$ to $2,599 \mathrm{~mm}$ annual rainfall in the northem and southern parts respectively (Olaoye, 2010). Abeokuta is the State capital and largest city in the state. Other towns and cities in the State include Ijebu-ode, Sagamu, Ijebu Igbo, Ilaro, Ayetoro, Mowe, Ibafo and Otta among others. Ogun State covers 16,762 square kilometres with a population of 3,728,098 and with more males than females (NPC, 2007). O gun State is made up of six ethnic groups viz, the Egba, the Ijebu, the Remo, the Yewa, the Awori and the Egun people. The state has three (3) Senatorial Districts viz: O gun Central Senatorial D istrict, O gun East Senatorial D istrict and Ogun West Senatorial District and twenty (20) Local G overnment Areas.

The populations for this study consisted of children, parents, teachers and social workers in Ogun State, Nigeria. D ata were obtained from parents and children with the aid of different copies of interview guide while different copies of structured questionnaires were administered to the teachers and social workers. A total of 243 rural and urban dwellers of O gun State comprising of 90 children, 65 parents, 60 teachers and 28 social workers were surveyed through the multistage sampling technique described below:
Stage 1 involves the purposive selection of Abeokuta South local government area since it is the only local government area that is purely urban in Ogun State. The second stage involves the random selection of two (2) out of the remaining nineteen (19) local government areas in the state to serve as the rural component of the study. The other selected LGAs were O bafemi Owode and Sagamu LGAs. This was followed by the random selection of one public secondary school from each of the selected local government areas. Schools serve as the core area for sampling the respondents since both teachers and children can be interviewed simultaneously. Secondary schools were used because students from secondary schools are older, more matured and expected to give better responses than their younger ones in primary schools. The final stage involves the random selection of $50 \%$ of teachers and $30 \%$ of children (from two classes - one junior class and one senior class) which resulted into 60 teachers and 100 children from the selected schools. Only $90 \%$ of the responses obtained from children were useful for this study. Seventy parents were conveniently sampled from the host communities of the schools since no sampling frame of parents was available for this study. Of these parents, only $92.9 \%$ (65) responded to all questions while the remaining 5 failed to make complete responses due to time constraints and their busy schedule. Thirty (30) social workers that attended the meetings of Child Protection Network (CPN) and Coalition of Non-Governmental Organizations in Ogun State (CONGOS) held on 28th February and 27th March, 2013 were interviewed but only $93.3 \%$ of them returned the questionnaires with useful responses while the remaining two did not return the questionnaires. 
SOCIETAL AWARENESS OF THE CHILD'S RIGHTS ACT AMONG RURAL AND ...

Table 1 indicated that 37 percent of the respondents were children, $26.7 \%$ and $24.7 \%$ were parents and teachers respectively while just $11.5 \%$ represented the social workers. More children than any other stakeholder categories were sampled because they are the primary stakeholders whose rights are being violated on a daily basis and whose participation is highly essential in order to ensure effective CRA implementation. Table 1 further reveals that 58.8 percent of the respondents were sampled from rural areas while the remaining $41.2 \%$ came from urban areas.

\section{Table 1: Selection of stakeholder categonies from rural and urban areas of $\mathbf{0}$ gun State}

\begin{tabular}{llll}
\hline Stakeholder categories & Rural & Urban & Total \\
\hline Children & $63(70.0)^{*}$ & $27(33.3)$ & $90(37.0)$ \\
Parents & $40(61.5)$ & $25(38.5)$ & $65(26.7)$ \\
Teachers & $40(66.7)$ & $20(33.3)$ & $60(24.7)$ \\
Social workers & - & $28(100.0)$ & $28(11.5)$ \\
All & $143(58.8)$ & $100(41.2)$ & $243(100.0)$ \\
\hline
\end{tabular}

\section{* Figures in parentheses were expressed in percentages}

The reliability of the instruments used in this study was ascertained through the split half technique by dividing the items in each instrument into two halves and then correlating the relationships between the two halves in each instrument using the Pearson's Product Moment Correlation analysis. The correlation coefficients for the different instruments ranged from 0.75 to 0.86 .

\section{Measurement of variables}

Awareness of CRA was measured nominally as Aware and Not aware. Those that were aware of the Act were further required to indicate their source(s) of awareness and their agencies that sponsored the awareness programmes. The frequency of awareness of CRA was determined as very often, often and once in a while the extent to which the respondents had contact with the CRA was measured as whether they have seen the Act or not and whether they possess the Act or not.

\section{Analytical technique}

D ata obtained from the data collection instruments were subjected to descriptive and inferential statistical analyses. The descriptive statistics such as percentage, mean and frequency distribution were used to present the data in charts and tables. Chi-square value was calculated and compared with $\chi^{2}$ tab in order to test for the validity of the null hypothesis of this study at $5 \%$ level of significance.

\section{RESULTS AND DISCUSSION Personal and social characteristics of re- spondents}

As indicated in Table 2, more than half $(56.79 \%)$ of the sampled residents of Ogun State were females (either girls or women), approximately two out of every three of the respondents were Christians by faith while about 30\% and less than 3\% practiced Islam and traditional religion respectively. This confirms that the two major religions in Ogun State, like other Nigerian states, are 
Christianity and Islam. Aside from the chil- within the country. More than three-quarter dren, $17.65 \%$ of the respondents were of the respondents came from the monoganever married and close to $70 \%$ of the adult mous family structure implying that higher respondents were married while others proportion of Ogun State residents were no (divorced, widowed and separated) consti- longer practicing the polygynous family type. tuted about $13.07 \%$. This shows that the Close to two-thirds $(62.90 \%)$ of the responmarriage institution is cherished in the dents also had post-secondary education Ogun State, like other states of the federa- while only about $6.40 \%$ had no formal edution. About 88.48 percent of the respon- cation. This is an indication residents in the dents were indigenes of Ogun State while selected areas of O gun State had high level 11.52 percent were non-indigenes from of education. Also, more than half $(53.50 \%)$ other ethnic groups such as Ibo and Hausa. of the residents had family sizes of 1-5 while This implies that Ogun State accommodates 44.44\% had 6-10 persons per household. people from other states and ethnic groups This is an indication that sampled residents

Table 2: Personal and social characteristics of respondents

\begin{tabular}{lll}
\hline Personal and social characteristics & Frequency & Percentage (\%) \\
Sex & & \\
Male & 105 & 43.21 \\
Female & 138 & 56.79 \\
Religion & 74 & \\
Islam & 163 & 30.45 \\
Christianity & 6 & 67.08 \\
Traditional & & 2.47 \\
Marital status & 27 & 17.65 \\
Never married & 106 & 69.28 \\
Married & 9 & 5.88 \\
Divorced & 7 & 4.58 \\
Widowed & 4 & 2.61 \\
Separated & & \\
Nativity & 215 & 88.48 \\
Indigene & 28 & 11.52 \\
Non-indigene & & \\
Family structure & 184 & 75.72 \\
Monogamy & 59 & 24.28 \\
Polygamy & & \\
Level of educational attainment* & & 14.38 \\
Completed primary education & 22 & 16.99 \\
Completed secondary education & 26 & 62.09 \\
Post-secondary education & 95 & 6.54 \\
No formal education & 10 & \\
Family size & & 53.50 \\
1-5 & 130 & 44.44 \\
6-10 & 108 & 2.06 \\
11-15 & 5 & \\
\hline
\end{tabular}

*Children were exempted from the calculations.

Source: Field survey (2013) 
SOCIETAL AWARENESS OF THE CHILD'S RIGHTS ACT AMONG RURAL AND ...

Awareness of CRA

Figure 1 reveals that majority (69.14\%) of the respondents was aware of the CRA and this is because different groups of stakeholders were involved in the study. It is also because most respondents (especially teachers, social workers and children) had more than primary level of education (Table 2) since education is an essential element in the promotion of any awareness programme. The finding of this study is in disagreement with that of Okoye (2011) which reported only about $32 \%$ of Nsukka residents being aware of the Act. A reason for this is the non-domestication of the CRA in Enugu state where Okoye conducted his study (Akor, 2009). Hence, it can be inferred that domesticating the Act is the first most important step to be taken by any state government in raising the awareness of the Act in order to protect children rights. As also depicted in Figure 1, many (83\%) of the urban residents were aware of the CRA than those in rural areas with only $59.44 \%$ being aware of the Act. This implies that awareness of the CRA increases as we move from rural areas to urban cities, thus, awareness of CRA is a function of residents' area of residence.

\section{Awareness of CRA by area of residence}

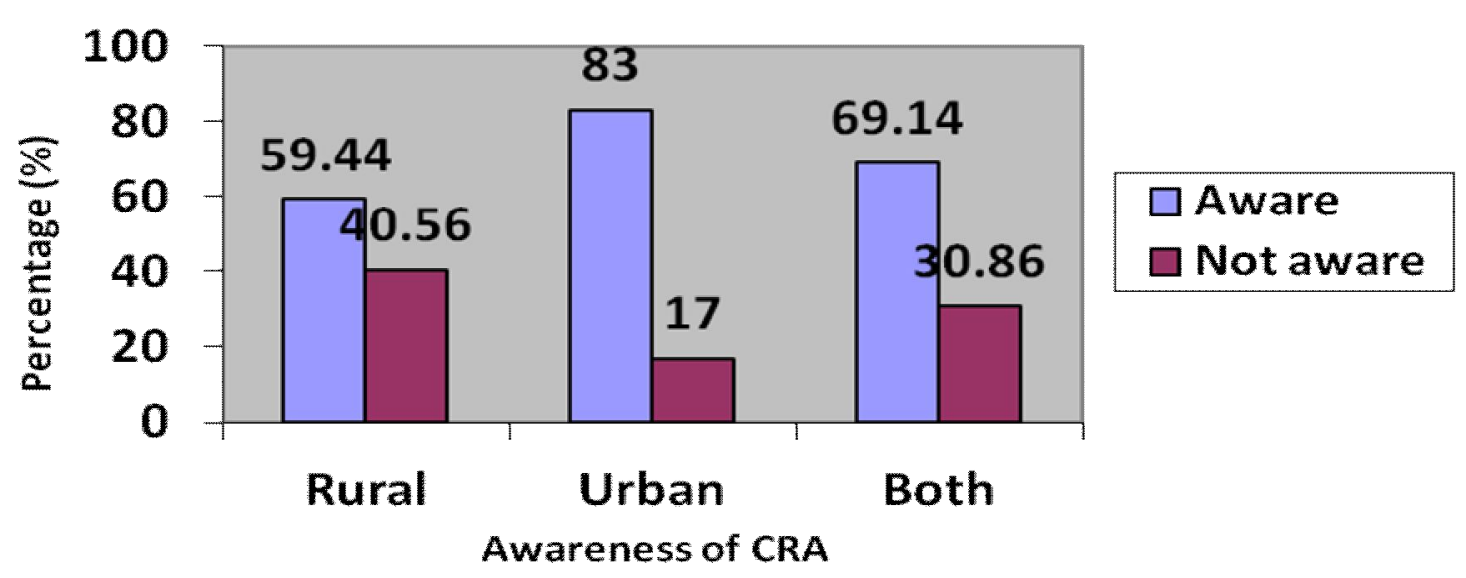

Figure 1: Percentage distribution of Ogun State residents in rural and urban areas by their awareness of CRA

Source: Field survey (2013)

\section{Sources of awareness}

Table 3 shows that radio $(42.86 \%)$ and television $(42.86 \%)$ were the most common sources of awareness of CRA by the residents of Ogun State. These were followed by awareness rally $(39.29 \%)$, newspapers $(36.31 \%)$ and handbills $(14.88 \%)$ respectively. Table 3 further shows that while awareness rallies seem to be the most com- mon source in urban areas, rural dwellers depended most on radio. This is partly because most social organizations that carried out awareness campaign programmes on CRA were closer to the urban cities than the rural areas and partly because most of the rural dwellers depended on the use of transistor radios as their source of information. Furthermore, Table 3 reveals that television, 
newspaper and handbills/ pamphlets were sources of awareness of CRA are more availmore common sources of awareness of able to and/ or accessible to the urban resiCRA among the urban residents than the dents than the rural dwellers. rural residents. This is because these

Table 3: Percentage distribution of respondents in rural and urban areas of 0 gun State by sources of awareness of CRA

\begin{tabular}{llll}
\hline Sources of awareness & Rural $(\mathrm{n}=85)$ & Urban $(\mathrm{n}=83)$ & All $(\mathrm{n}=168)$ \\
\hline Radio & $44(51.76)^{*}$ & $28(33.73)$ & $72(42.86)$ \\
Television & $32(37.65)$ & $40(48.19)$ & $72(42.86)$ \\
Newspaper & $18(21.18)$ & $43(51.81)$ & $61(36.31)$ \\
Handbills/pamphlets & $5(5.88)$ & $20(24.10)$ & $25(14.88)$ \\
Awareness campaigns & $12(14.12)$ & $54(65.06)$ & $66(39.29)$ \\
\hline
\end{tabular}

*Figures in parentheses were expresses in percentages. Multiple responses also occurred.

Source: Field survey (2013)

Sponsorship of awareness programmes

Figure 2 reveals that residents of Ogun State became aware of the CRA through programmes that were mainly sponsored by government agencies only (56.55\%). As also depicted in figure 2, more of the rural residents $(65.88 \%)$ than their urban counterparts (46.99\%) became aware of CRA through government sponsored programmes only while more of the urban resi- dents $(27.71 \%)$ than their rural counterparts $(8.24 \%)$ became aware of the CRA through both government agencies- and nongovernmental organizations- sponsored programmes. This implies that urban residents had more access to programmes sponsored by both organizations either through the television, radio, awareness campaigns and newspapers than their rural counterparts.
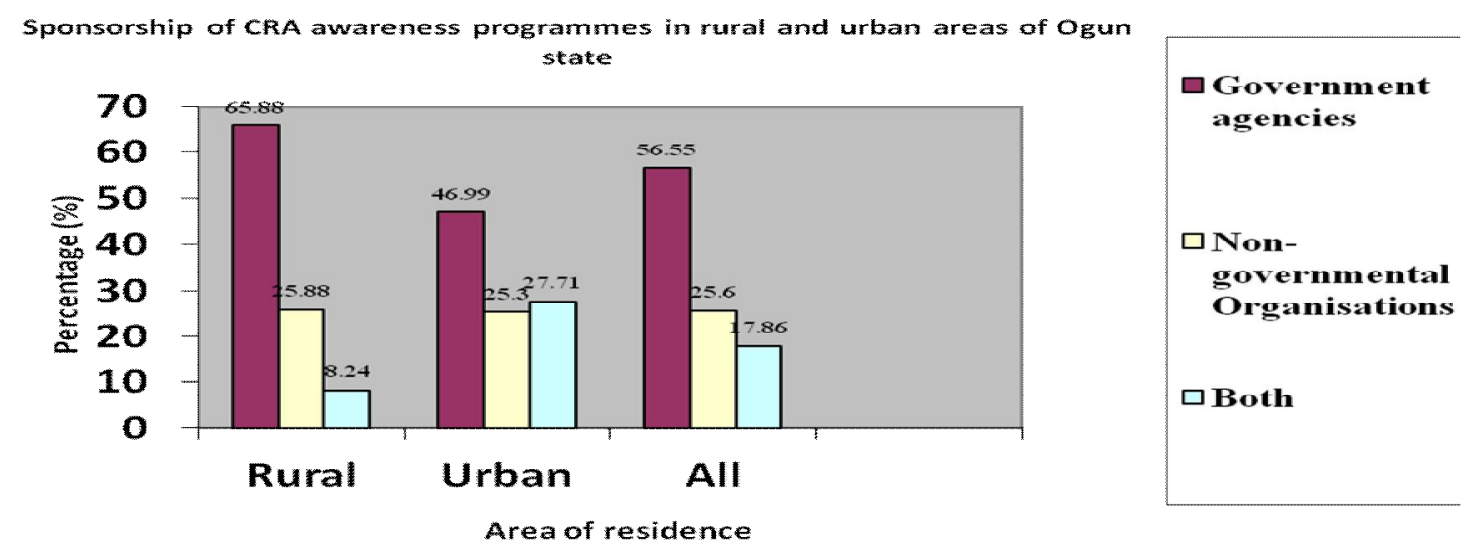

Figure 2: Percentage distribution of 0 gun State residents in nural and urban areas by their sources of awareness of CRA Source: Field survey (2013) 
SOCIETAL AWARENESS OF THE CHILD'S RIGHTS ACT AMONG RURAL AND ...

Contact with CRA

Table 4 reveals that $40.48 \%$ and $20.24 \%$ of Ogun State residents had seen and possessed at least a copy of the CRA respectively. This implies that a reasonable proportion of those who were aware of the CRA had never seen it with their own eyes not to talk of having the document in their possession. Hence, their knowledge and understanding of the Act is likely to be less and hence, the reason for the prevalence of the different forms of acts that violates the child's rights. These data also show that exactly half of those who had seen the Act possessed at least a copy of it. Furthermore, Table 4 shows that more of the urban residents in Ogun State (44.58\% and $24.10 \%)$ than their rural counterparts $(36.47 \%$ and $16.47 \%$ ) had seen and possessed at least a copy of the CRA before. This portrays that more of the urban residents were in contact with the Act than their rural counterparts and also explains why more urban than ru- ral residents were aware of the CRA in O gun State.

Frequency with which the Act was heard As illustrated in Table 5, only $30.36 \%$ of those who were aware of the Act have heard it once in a while, while $35.12 \%$ and $34.54 \%$ have heard of the CRA frequently and very frequently respectively. The mean values in Table 5 further shows that urban residents (mean frequency $=2.18$ ) have heard of CRA more frequently than their rural counterparts $($ mean frequency $=1.91)$.

Association between residents' area of residence and the awareness of CRA in Ogun State

As indicated in Table 6, a significant association exists between the respondents' area of residence and their awareness of CRA at 5\% level of significance since $\chi^{2}$ cal $(15.2985)>$ $\chi^{2}$ tab (3.841). This further supports the fact that urban residents were significantly more aware of CRA than their rural counterparts.

Table 5: Distribution of respondents by the frequency with which they heard about the Act

\begin{tabular}{llll}
\hline Frequency & Rural $(\mathrm{n}=85)$ & Urban $(\mathrm{n}=83)$ & Both $(\mathrm{n}=168)$ \\
\hline Very frequently & $22(25.88)^{*}$ & $36(43.37)$ & $58(34.52)$ \\
Frequently & $33(38.82)$ & $26(31.33)$ & $59(35.12)$ \\
Once in a while & $30(35.29)$ & $21(25.30)$ & $51(30.36)$ \\
Mean & 1.91 & 2.18 & 2.04 \\
\hline
\end{tabular}

*Figures in parentheses were expresses in percentages

Source: Field survey (2013)

Table 6: Result of Chi-square analysis showing the association between the awareness of CRA by residents and their area of residence

\begin{tabular}{lllll}
\hline Variables & $\mathrm{df}$ & $\chi 2 \mathrm{cal}$ & $\chi 2 \mathrm{tab}(\mathrm{p}=0.05)$ & Decision \\
$\begin{array}{l}\text { Awareness of CRA versus area of } \\
\text { residence }\end{array}$ & 1 & 15.2985 & 3.841 & $\begin{array}{l}\text { Significant association } \\
\text { exists }\end{array}$ \\
\hline
\end{tabular}

Source: Field survey (2013) 


\section{CONCLUSION AND RECOMMENDATION}

It can be concluded from the findings of this study that:

- Majority of Ogun State's residents were aware of the CRA and that awareness of CRA is higher in urban cities than in rural areas.

- Radio and television were the two most common means through which the residents became aware of CRA. The most common means peculiar to the rural and urban residents were radio and awareness campaigns respectively.

- Sponsorship of awareness programmes is more common with government agencies than nongovernmental organizations in both rural and urban areas of the state.

- Less than half of those who claimed to be aware of the CRA had seen at least a copy of the CRA and exactly half of those who had seen a copy of the Act had at least a copy of it in possession. Hence, as regards contact with the CRA, urban residents had been in contact with the CRA than their rural counterparts.

Based on the aforementioned, this study recommends that:

- States that are yet to domesticate the Act should do so in order to raise the awareness of children's rights in all the States of the Federation and hence, protecting all the Nigerian children;

- Awareness programmes in Ogun
State should be intensified especially in the rural areas in order to give children equal opportunities to develop in both rural and urban areas.

- Copies of the Child's Rights Act should be made available to all residents of Ogun State in forms that can be easily understood by them to improve their contact with the CRA and also raise its awareness among residents.

- Both the government agencies and non-governmental organizations should sponsor more programmes that will be specifically directed to raising residents' awareness of CRA in rural areas of the state.

\section{REFERENCES}

Adimula, B. 2005. An overview of the Nigerian Child Rights Act, 2003: K wara state as case study. Nigeian BarJaumal, 3(3): 11-20

African Child Policy Forum. 2012. Harmonisation of children's laws in Nigeria. ChildLawResarces, 2: 1-13

Agbonlahor, M. U., Momoh, S., Bamire, S., Oke, J. T. 2007. D eterminants of child labour in rural households of O gun State, Nigeria. ASSET seies C, 2(1), 97-108.

Akor, G. 2009. Nigeria: Child Rights AbuseProduct of inefficient leadership. Retrieved from http:/ / allafrica.com/ stories/ 200910201191.html

Akwara, A. F., Soyibo, A. G., Agba, M. S. 2010. Law and children's rights protection: The nexus for a sustainable development in Nigeria. Camadian Social Säene, 6(2): 26-33 
Awosola, R. K., Omoera, 0. S. 2008. Child rights and the media: The Nigerian experience. StudHumCommSá, 2 (2): 125131

Bamgboye, A. 2011. Group laments apathy over child rights Act. D aily Trust Tuesday. Retrieved from dailytrust.dailytrust.com/ index.php?...child-rights-act

Ejieh, M. U. C., Akinola, O. B. 2009. Children's rights and participation in schools: Exploring the awareness level and views of Nigerian primary school children. Elementary Eduration Online 8 (1): 176-182. Available on http:/ / ikogretim-online.org.tr

Federal Govemment of Nigeria. 1999. The Constitution of the Federal Republic of Nigeria (Promulgation) 1999 No. 24

Gbadamosi, B. 2003. Problems and prospects of implementing the primary education component of the National Policy on Education in O gun State. Jamal of Eduration Advancement, 5(5):54-57

National Population Commission N PC. 2007. The 2006 population census of the federal republic of Nigeria: Analytical report at the national level. Lagos, Nigeria: NPC

Ojebiyi, W. G. 2010. Effects of peakseason agricultural activities on the educational performance of rural children in Odeda local government area of O gun State. An unpublished undergraduate project submitted to the Department of Agricultural Extension and Rural D evelopment, University of Agriculture Abeokuta, Nigeria.

Ojo, M. O. 0. 2013. A sociological investigation of the determinant factors and the effects of child street hawking in Nigeria:

Agege, Lagos state under survey. Intemational Ja mal of Asian Social Saiene, 3(1), 114-137. Retrieved from http:/ / www.aessweb.com/ journal-detail.php?id=5007

O koye, U. 0. 2011. Knowledge and awareness of the Child's Rights Act among residents of a university town in Enugu state, Nigeria. Intemational RescarchJamals, 2(10), 1595-1601. Retrieved from http:/ /

www.interes journals.org/ ER

Olaoye, 0. J. 2010. Dynamics of the adoption process of improved fisheries technologies in Lagos and O gun States, Nigeria. An unpublished Ph.D thesis submitted to the D epartment of Aquaculture and Fisheries Management, University of Agriculture, Abeokuta, 337pp.

Omotor, G. D. 2002. Proper environment and sustainable development: A review. African Jaumal of Environmental Studies, 1(1\&2):2131

Owasanoye, B., Adekunle, A. 1996. O verview of the rights of the child in Nigeria. . In I. A. Ayua \& I. E. O kagbue (Eds.), Therigts of thedildin Nigeia(Pp. 28-60). Lagos, Nigeria: Nigerian Institute of Advanced Legal Studies.

Tang, K. 2003. Implementing the United Nations' Convention on the Rights of the Child: The Canadian experience. Intemational Soial Work, 46: 277-288

United Nations Intemational Children's Emergency Fund - UN ICEF. 2006. Violence against children. In: UNICEF (Ed.). Child protetioninformation shet.

UN ICEF. 2007. Information fact sheet: 
W. G. OJEBIYI, O. R., ASHIMO LOWO, T. O . A. BANMEKE AND A. M. ARIYO

The child's Rights Act. Published by Author UN ICEF. 2011. UNICEF Nigeria - Factin August, 2007.

sheet: Child rights legislation in Nigeria

(Manuscipt recived 7thNowenber, 2016; accepted 3rd June, 2015 